\title{
Bohseit z beryl-columbitového pegmatitu D6e v Maršíkově (silezikum, Česká republika)
}

\author{
Bohseite from beryl-columbite pegmatite D6e in Maršíkov (Silesicum, Czech Republic)
}

\author{
Zdeněk Dolníček ${ }^{1)^{*}}$, Miroslav Nepejchal ${ }^{2)}$, JiŘi Sejkora ${ }^{1)}$, Jana Ulmanová ${ }^{1)}$ \\ A ŠTĚ́PÁN CHLÁDEK ${ }^{3)}$
}

${ }_{11}^{1}$ Mineralogicko-petrologické oddělení, Národní muzeum, Cirkusová 1740, 19300 Praha 9;

*e-mail: zdenek.dolnicek@nm.cz

2) Žižkova 8, 78701 Šumperk

3)Katedra geologického inženýrství, Hornicko-geologická fakulta, VŠB - Technická univerzita Ostrava, 17. listopadu 15, 70833 Ostrava-Poruba

DolničEk Z, Nepechal M, Sejkora J, Ulmanová J, Chládek Š (2020) Bohseit z beryl-columbitového pegmatitu D6e v MarŠíkově (silezikum, Česká republika). Bull Mineral Petrolog 28(1): 219-223 ISSN 2570-7337

\begin{abstract}
Bohseite was found in a lenticular body of D6e beryl-columbite granitic pegmatite near Maršíkov, which is hosted by amphibole gneisses of the Sobotín Amphibolite Massif (Silesicum, northeastern part of Czech Republic). Bohseite forms chalky white aggregates up to $1 \mathrm{~cm}$ in size, which are hosted by small vugs in the coarse-grained pegmatite. It is associated with small crystals of quartz, adularia, albite, muscovite and epidote. Bohseite is orthorhombic, space group $\mathrm{Cmcm}$ with following unit-cell parameters refined from X-ray powder diffraction data: a 23.210(2), b 4.955(2), c 19.428(3) $\AA$ and $V$ 2234.5(1.0) $\AA^{3}$. The electron microprobe compositional data of bohseite are presented. Bohseite from Maršíkov contains 14.3 - 42.5 mol. \% of bavenite component, up to 0.06 apfu $\mathrm{Na}$ and $0.13-0.36$ apfu F. The association with other beryllium-rich phases (milarite, bertrandite) points to variable activities of Be and Al during hydrothermal stage of evolution of the pegmatite body. The likely source of Be was beryl, which is sometimes completely dissolved and vugs after its crystals are lined by small crystals of above mentioned hydrothermal phases.
\end{abstract}

Key words: bohseite, granitic pegmatites, hydrothermal alteration, Maršíkov, Silesicum, Bohemian Massif

Obdrženo 16. 5. 2020; prijato 17. 6. 2020

\section{Úvod}

Bohseit je vzácný kosočtverečný vodnatý silikát beryllia a vápníku s ideálním vzorcem $\mathrm{Ca}_{4} \mathrm{Be}_{4} \mathrm{Si}_{9} \mathrm{O}_{24}(\mathrm{OH})_{4}$, jenž byl nedávno popsán jako nový minerál Szełegem et al. (2017). Jeho typovou lokalitou je Piława Górna v Sovích horách (Polsko), kde se vyskytuje v granitickém pegmatitu jako alterační minerál vznikající pravděpodobně přeměnou berylu. Bohseit je doposud zmiňován jen ze šesti dalších světových lokalit, mezi nimiž dominují pegmatitové výskyty bohaté na Be (pegmatit Tatjana, masiv Khaldzan Buragtag, Mongolsko; ložisko Jermakovskoe, Zabajkalí, Rusko; pegmatit Nedre Lapplægret, Drag, Norsko; pegmatity Høydalen a Heftetjern, Tørdal, Norsko) a samostatné postavení má lokalita Kangerluarsuk Fjord v alkalickém komplexu llímaussaq v Grónsku (www.mindat.org). V rámci České republiky nově uvádějí bohseit z NYF pegmatitů v syenitech třebíčského masivu Zachař a Škoda (2019).

Bohseit je izostrukturní $s$ bavenitem $\mathrm{Ca}_{4} \mathrm{Be}_{2} \mathrm{Al}_{2}$ $\mathrm{Si}_{9} \mathrm{O}_{26}(\mathrm{OH})_{2}$, S nímž vytváří izomorfní řadu. Složení minerálů řady bohseit-bavenit Ize obecně vyjádřit vzorcem $\mathrm{Ca}_{4} \mathrm{Be}_{4-\mathrm{x}} \mathrm{Al}_{\mathrm{x}} \mathrm{Si}_{9} \mathrm{O}_{24+\mathrm{x}}(\mathrm{OH})_{4-\mathrm{x}}$, príčemž parametr $\mathrm{x}$ může nabývat hodnot od 0 (čistý koncový člen bohseit) do 2 (čistý koncový člen bavenit).

$\checkmark$ této práci přinášíme nové poznatky o dalším výskytu bohseitu v rámci ČR, který byl zjištěn při determinaci nerostného materiálu nově odebraného druhým z autorů této práce $z$ berylového pegmatitu D6e u Maršíkova. Bohseit zde byl identifikován prostřednictvím práškové rentgenové difrakce a chemických analýz z elektronové mikrosondy. Dokladový materiál $k$ této studii je uložen ve sbírkách Národního muzea v Praze.

\section{Geologická pozice a mineralogie pegmatitu D6e}

Okolí Maršíkova je známo řadou výskytů mineralogicky zajímavých pegmatitových těles. Vedle dvou světoznámých lokalit (Scheibengraben, Schinderhübel) jsou zde i další drobnější tělesa, která většinou $v$ minulosti nebyla předmětem podrobnějších mineralogických výzkumů. Jedním z nich je i beryl-columbitový pegmatit označovaný D6e, který se nachází na jz. svahu kóty $565 \mathrm{~m} \mathrm{n}$. m. $v$ blízkosti rozcestí silnice Sobotín - Maršíkov. $\vee$ minulosti byly z lokality známy jen volné balvany pegmatitu, z nichž byly Dostálem (1964) a Krut'ou et al. (1968) ze vzácnějších minerálů popsány výskyty berylu, bavenitu, columbitu a granátu. Novodobá (2016 - 2020) aktivita sběratelů minerálů na lokalitě vedla k odkrytí primárního výchozu pegmatitového tělesa (obr. 1 a 2). Pegmatit D6e má čočkovitý tvar a je uložen konformně s foliací okolních amfibolických rul, náležejících $\mathrm{k}$ sobotínskému amfibolitovému masivu. Délka pegmatitového tělesa činí asi 12 - 15 m a jeho ma- 
ximální mocnost je $2.2 \mathrm{~m}$. Směr tělesa je SSV - JJZ se sklonem $65^{\circ} \mathrm{k}$ VJV. Pegmatit je složen z několika texturně-paragenetických jednotek. Na okraji tělesa je vyvinuta málo mocná aplitická jednotka (křemen + K-živec + albit + biotit). Hlavní část objemu pegmatitu tvoří muskovitická hrubě zrnitá jednotka (křemen + K-živec + albit + muskovit \pm biotit \pm beryl), následovaná nevýrazně vyvinutou grafickou jednotkou (K-živec + křemen), jednotkou blokového živce (K-živec + křemen + muskovit + beryl) a křemenným jádrem. Hrubě zrnitá a bloková jednotka jsou lokálně intenzívně albitizovány. Vedle hlavních horninotvorných minerálů (křemen, albit, K-živec, muskovit, biotit) byla $v$ nově odebraném materiálu z výchozu žily D6e identifikována i řada dalších vzácnějších fází. Nejcharakterističtější jsou obecný beryl v krystalech až $15 \times 10 \times 10 \mathrm{~cm}$ velkých a minerály columbitové skupiny, které klasifikačně odpovídají zejména columbitu-( $\mathrm{Mn})$ a méně často columbitu-(Fe). Na trhlinách columbitu byly zjištěny i mikrolit a fersmit. Dále se vykytuje granát almandin-spessartinového složení a křídově bílý bavenit o velikosti až $3 \times 3 \mathrm{~cm}$. $Z$ dalších akcesorií byl zjištěn zirkon, fluorapatit a uraninit. $\checkmark$ drobných dutinkách $v$ hrubě zrnité či blokové jednotce pegmatitu (zčásti vzniklých vyloužením berylu) byla identifikována pestrá asociace mladších hydrotermálních minerálů - albitu, aduláru, křemene, muskovitu, epidotu a bertranditu (Chládek, Uher 2020). Běžné jsou na lokalitě také agregáty bílého až světle zelenavého milaritu o velikosti do $5 \mathrm{~cm}$, pravděpodobně několika generací.

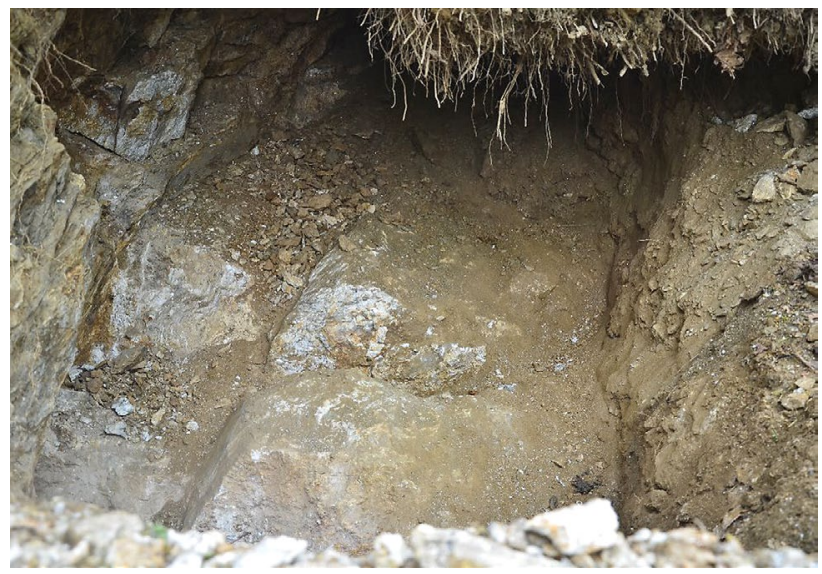

Obr. 1 Kontakt pegmatitu D6e ( $v$ pravé části snímku) $s$ okolní rulou (v levé části), odkrytý výkopem. Stav z 15. 5. 2020, foto M. Nepejchal.

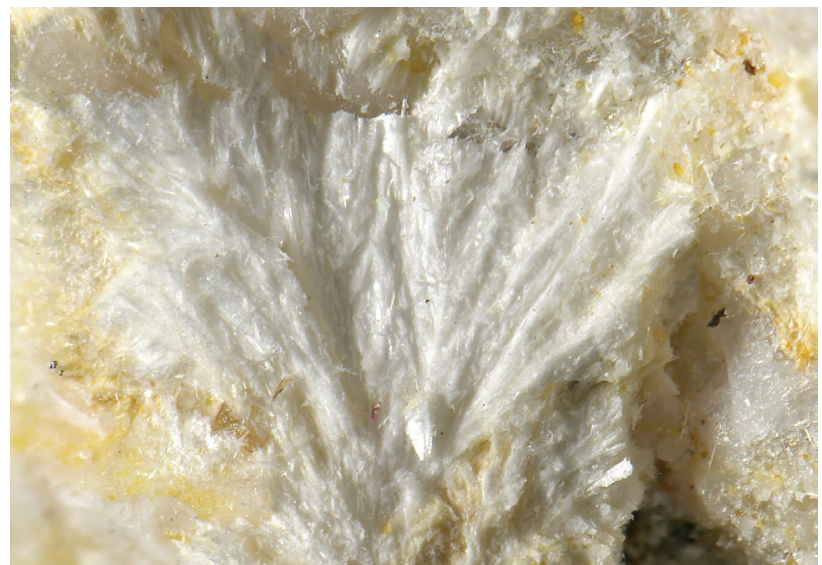

Obr. 3 Vějiřrovitý křídově bilý agregát bohseitu složený z jehličkovitých krystalů; šiřka záběru $4 \mathrm{~mm}$; foto J. Sejkora.

\section{Materiál a metodika}

Studované vzorky byly odebrány druhým z autorů předložené studie (MN) z výkopu na výchozu pegmatitu D6e, vyhloubeném sběrateli minerálů $v$ posledních letech. Makrofotografie vzorků bohseitu byly pořízeny pomocí mikroskopu Nikon SMZ 25 s digitální kamerou Nikon DS-Ri2 za použití funkce skládání obrazu v programu NIS Elements AR verze 4.20.

Rentgenová prášková difrakční data byla získána pomocí práškového difraktometru Bruker D8 Advance (Národní muzeum, Praha) s polovodičovým pozičně citlivým detektorem LynxEye za užití CuKa záření (40kV, 40 mA). Práškové preparáty byly naneseny $v$ acetonové suspenzi na nosič zhotovený z monokrystalu křemíku a následně pak byla pořízena difrakční data ve step-scanning režimu (krok $0.01^{\circ}$, načítací čas $8 \mathrm{~s} / \mathrm{krok}$ detektoru, celkový čas experimentu cca 15 hod.). Pozice a intenzity jednotlivých difrakčních maxim byly zpřesněny pomocí programu ZDS (Ondruš 1993) za užití profilové funkce Pearson VII. Mřížkové parametry byly zpřesněny metodou nejmenších čtverců pomocí programu Burnhama (1962), iniciální hodnoty byly použity z práce Szełeg et al. (2017).

$Z$ reprezentativních vzorků byly následně vyseparovány mineralogicky zajímavější partie a z nich byly autory zhotoveny naleštěné zalévané preparáty. Následně byly nábrusy vakuově napařeny uhlíkovou vrstvou o tloušt'ce $30 \mathrm{~nm}$ a studovány na elektronové mikrosondě Cameca

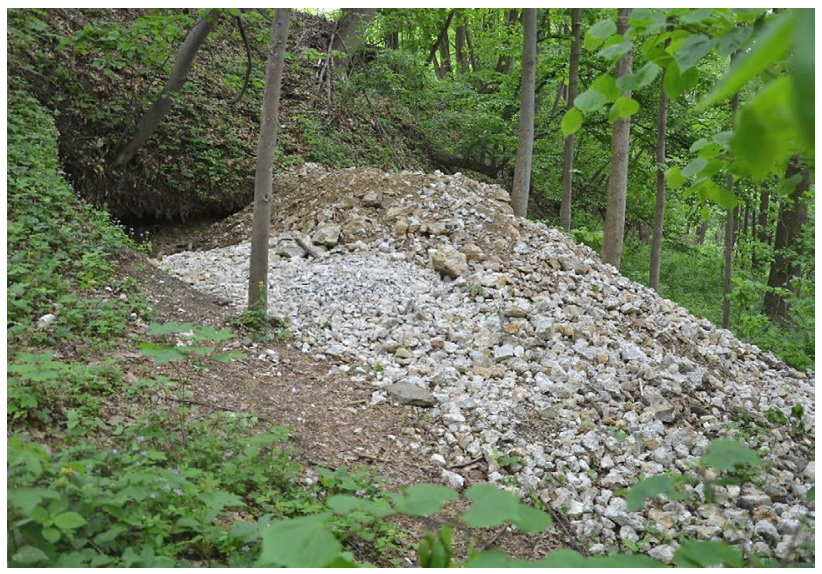

Obr. 2 Odval před výkopem na výchozu pegmatitu D6e. Stav z 15. 5. 2020, foto M. Nepejchal.

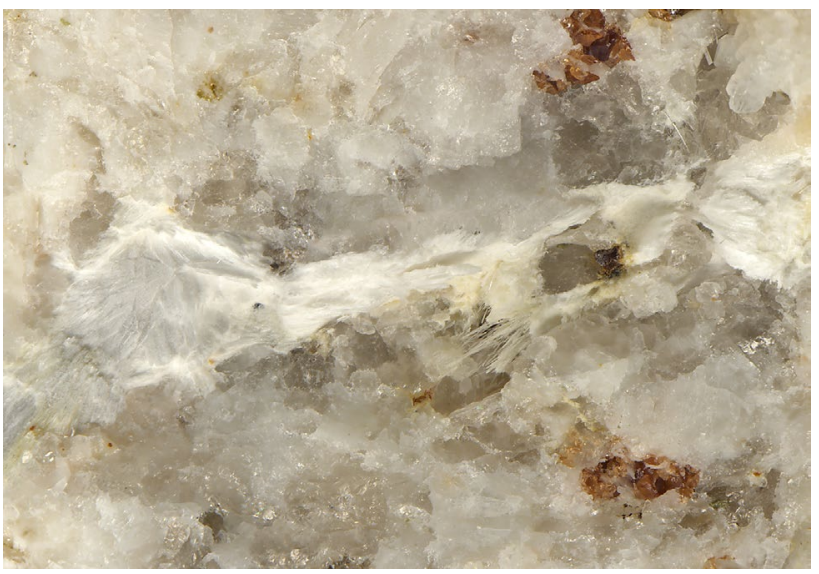

Obr. 4 Jemně jehličkovité křídově bílé agregáty bohseitu $v$ dutině pegmatitu; šiřka záběru $13 \mathrm{~mm}$; foto J. Ulmanová. 
SX-100 (Národní muzeum, Praha). $\mathrm{Na}$ přístroji byly pořízeny snímky ve zpětně odražených elektronech (BSE), provedena identifikace jednotlivých fází pomocí energiově disperzních (EDS) spekter a kvantitativně měřeno chemické složení bohseitu ve vinově disperzním (WDS) modu. Při kvantitativních analýzách bohseitu byly použity následující podmínky: urychlovací napětí $15 \mathrm{kV}$, proud svazku $10 \mathrm{nA}$ a průměr elektronového svazku $5 \mu \mathrm{m}$. Měřeny byly obsahy $\mathrm{Al}, \mathrm{Ba}, \mathrm{Ca}, \mathrm{Cl}, \mathrm{Cs}, \mathrm{Cu}, \mathrm{F}, \mathrm{Fe}, \mathrm{K}, \mathrm{Mg}$, $\mathrm{Mn}, \mathrm{N}, \mathrm{Na}, \mathrm{P}, \mathrm{Rb}, \mathrm{S}, \mathrm{Si}$ a Sr. Při analýzách byly použity následující standardy a analytické čáry: albit (NaKa), apatit (PKa), baryt (BaL $\beta), B N(N K \alpha)$, celestin (SrL $\beta$, SK $\alpha)$, Cs-sklo (CsL $\alpha)$, diopsid $(\mathrm{MgK \alpha})$, halit $(\mathrm{ClK} \alpha)$, hematit (FeKa), chalkopyrit (CuKa), LiF (FKa), Rb-Ge-sklo (RbLa), rodonit $(\mathrm{MnK \alpha})$, sanidin (KKa, SiKa, AlKa) a wollastonit (CaKa). Měřící časy na píku se pohybovaly obvykle mezi 10 a $30 \mathrm{~s}$ (pro dusík $120 \mathrm{~s}$ ), měřící časy pozadí trvaly polovinu času měření na píku. Načtená data byla přepočítána na obsahy oxidů vyjádřené v hm. \%, s použitím standardní PAP korekce (Pouchou, Pichoir 1985) a s automatickým dopočtem obsahu Be do $100 \%$. Obsahy výše uvedených prvků, které nejsou uvedeny v tabulce minerálních analýz, byly ve všech př́padech pod mezí stanovitelnosti.
Tabulka 1 Rentgenová prášková data bohseitu z pegmatitu D6e z Maršíkova

\begin{tabular}{rrrrrrrrrrrr}
\hline$h$ & $k$ & $l$ & $d_{\text {obs. }}$ & $I_{\text {obs. }}$ & $d_{\text {calc. }}$ & $h$ & $k$ & $l$ & $d_{\text {obs. }}$ & $I_{\text {obs. }}$ & $d_{\text {calc. }}$ \\
\hline 2 & 0 & 0 & 11.605 & 18.4 & 11.605 & 8 & 0 & 4 & 2.4905 & 0.3 & 2.4907 \\
2 & 0 & 2 & 7.455 & 1.1 & 7.449 & 6 & 0 & 6 & 2.4833 & 0.3 & 2.4830 \\
4 & 0 & 2 & 4.982 & 4.0 & 4.981 & 1 & 1 & 7 & 2.4091 & 0.3 & 2.4085 \\
0 & 0 & 4 & 4.856 & 0.8 & 4.857 & 10 & 0 & 0 & 2.3208 & 9.3 & 2.3210 \\
3 & 1 & 0 & 4.172 & 0.4 & 4.173 & 9 & 1 & 1 & 2.2723 & 0.8 & 2.2719 \\
6 & 0 & 0 & 3.867 & 19.7 & 3.868 & 7 & 1 & 5 & 2.2488 & 0.3 & 2.2478 \\
4 & 0 & 4 & 3.725 & 5.8 & 3.724 & 10 & 0 & 4 & 2.0941 & 0.7 & 2.0942 \\
6 & 0 & 2 & 3.594 & 0.7 & 3.594 & 9 & 1 & 4 & 2.0698 & 0.4 & 2.0696 \\
5 & 1 & 0 & 3.390 & 0.7 & 3.388 & 5 & 1 & 8 & 1.9721 & 0.3 & 1.9738 \\
5 & 1 & 1 & 3.343 & 100.0 & 3.337 & 0 & 0 & 10 & 1.9424 & 0.4 & 1.9429 \\
0 & 0 & 6 & 3.239 & 3.2 & 3.238 & 12 & 0 & 0 & 1.9339 & 3.2 & 1.9341 \\
5 & 1 & 2 & 3.194 & 5.8 & 3.199 & 12 & 0 & 2 & 1.8966 & 0.4 & 1.8969 \\
2 & 0 & 6 & 3.120 & 1.1 & 3.119 & 9 & 1 & 6 & 1.8686 & 0.3 & 1.8684 \\
1 & 1 & 5 & 3.026 & 1.8 & 3.032 & 11 & 1 & 5 & 1.7367 & 0.6 & 1.7366 \\
4 & 0 & 6 & 2.828 & 0.3 & 2.828 & 6 & 0 & 10 & & & 1.7362 \\
8 & 0 & 2 & 2.780 & 2.2 & 2.780 & 14 & 0 & 0 & 1.6577 & 10.7 & 1.6578 \\
7 & 1 & 1 & 2.727 & 0.2 & 2.728 & 14 & 0 & 2 & 1.6340 & 0.8 & 1.6342 \\
3 & 1 & 6 & 2.559 & 0.2 & 2.558 & 14 & 0 & 4 & 1.5690 & 1.3 & 1.5690 \\
5 & 1 & 5 & 2.555 & 0.3 & 2.553 & 16 & 0 & 4 & 1.3900 & 0.2 & 1.3899 \\
7 & 1 & 3 & 2.536 & 0.4 & 2.536 & & & & & & \\
\hline
\end{tabular}

Tabulka 2 Parametry základní cely bohseitu a bavenitu (pro ortorombickou prostorovou grupu $\mathrm{Cmcm}$ )

\begin{tabular}{lccc}
\hline & bohseit & bohseit & bavenit \\
\hline & Maršíkov & Piława Górna & Lilly Pad Lake \\
\hline & tato práce & Szełeg et al. (2017) & Lussier, Hawthorne (2011) \\
\hline$a[\AA]$ & $23.210(2)$ & $23.204(6)$ & $23.2090(7)$ \\
$b[\AA]$ & $4.955(2)$ & $4.9442(9)$ & $5.0129(1)$ \\
$c[\AA]$ & $19.428(3)$ & $19.418(6)$ & $19.4494(6)$ \\
$V\left[\AA^{3}\right]$ & $2234.5(1.0)$ & 2227.7 & $2262.8(2)$ \\
\hline
\end{tabular}

Tabulka 3 Příklady chemického složení bohseitu z pegmatitu D6e z Maršíkova. Obsahy oxidů v hm. \%, hodnoty apfu jsou vypočitány na základ 9 atomů křemíku, obsah bavenitové molekuly v mol. \%. * - obsah dopočten ze stechiometrie substituce bohseit-bavenit.

\begin{tabular}{|c|c|c|c|c|c|c|c|c|c|c|c|c|c|c|}
\hline An. č. & 1 & 2 & 3 & 4 & 5 & 6 & 7 & 8 & 9 & 10 & 11 & 12 & 13 & \\
\hline$\overline{\mathrm{SiO}_{2}}$ & .93 & 59.40 & 59.21 & 58.56 & 59.50 & 59.50 & 59.23 & 9.77 & 59.73 & 9.14 & 9.02 & 59.50 & 8.34 & \\
\hline $\mathrm{I}_{2} \mathrm{O}_{3}$ & 1.59 & 1.74 & 1.79 & 2.12 & 2.38 & 2.66 & 2.76 & 3.01 & 3.38 & 3.74 & 3.91 & 4.13 & 4.24 & 4. \\
\hline $\mathrm{eO}^{\circ}$ & 0.12 & 10.13 & 10.08 & 9.79 & 9.84 & 9.70 & 9.60 & 9.58 & 9.39 & 9.11 & 9.00 & 8.98 & 8.71 & 8. \\
\hline $\mathrm{aO}$ & .43 & 24.72 & 24.61 & 24.36 & 24.63 & 24.54 & 24.62 & 24.75 & 24.87 & 49 & 24.63 & 24.59 & .44 & 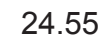 \\
\hline $\mathrm{a}_{2} \mathrm{O}$ & 0 & 0 & 0.06 & 0 & 0.08 & 0.16 & 0 & 0.07 & 0.06 & 0 & 0 & 0.07 & 0 & \\
\hline $\mathrm{H}_{2} \mathrm{O}^{*}$ & 3.36 & 3.41 & 3.46 & 3.17 & 3.34 & 3.32 & 3.33 & 3.26 & 3.15 & 3.08 & 3.04 & 3.08 & 2.97 & \\
\hline$F^{2}$ & 0.61 & 0.51 & 0.36 & 0.74 & 0.43 & 0.37 & 0.27 & 0.40 & 0.49 & 0.41 & 0.41 & 0.32 & 0.36 & 0. \\
\hline$=F$ & -0.26 & -0.21 & -0.15 & -0.31 & -0.18 & -0.16 & -0.11 & -0.17 & -0.21 & -0.17 & -0.17 & -0.13 & -0.15 & 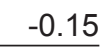 \\
\hline elkem & 3.78 & 99.70 & .42 & 98.43 & 0.02 & .09 & 9.70 & 0.67 & 36 & 99.80 & 99.84 & 54 & 98.91 & 00 \\
\hline $4+$ & 00 & 9.000 & 000 & 9.000 & 00 & 00 & 00 & 00 & 00 & 9.000 & 9.000 & 000 & 000 & \\
\hline$\left.\right|^{3+}$ & 0.286 & 0.311 & 0.321 & 0.384 & 0.424 & 0.474 & 0.494 & 0.534 & 0.600 & 0.671 & 0.703 & 0.736 & 0.771 & 0.8 \\
\hline $\mathrm{Be}^{2+*}$ & 3.713 & 3.687 & 3.681 & 3.615 & 6 & 3.525 & 3.504 & 3.466 & 99 & 3.331 & 3.297 & 263 & 3.228 & 3.1 \\
\hline $\mathrm{Be}+\mathrm{Al}$ & 3.999 & 3.998 & 4.002 & 3.999 & 00 & 99 & 3.999 & 00 & 99 & 4.002 & 4.000 & 000 & 3.999 & 4.00 \\
\hline $\mathrm{Ca}^{2+}$ & 998 & 4.013 & 4.008 & 4.012 & 3.992 & 3.977 & 4.009 & 3.993 & 4.015 & 3.993 & 4.024 & 3.985 & 4.040 & 3.9 \\
\hline $\mathrm{Na}^{+}$ & 0 & 0 & 0.018 & 0 & 0.023 & 0.047 & 0 & 0.020 & 0.018 & 0 & 0 & 0.021 & 0 & \\
\hline $\mathrm{Ca}+\mathrm{Na}$ & 3.998 & 4.013 & 4.026 & 4.012 & 4.015 & 4.024 & 4.009 & 4.014 & 4.033 & 3.993 & 4.024 & 4.006 & 4.040 & 3.9 \\
\hline$\overline{\mathrm{OH}^{-*}}$ & 424 & 3.448 & 3.509 & 3.251 & 3.371 & 3.351 & 3.376 & 3.275 & 3.167 & 3.128 & 3.093 & 3.109 & 3.057 & 2.9 \\
\hline $\mathrm{F}^{-}$ & 0.295 & 0.244 & 0.173 & 0.360 & 0.206 & 0.177 & 0.130 & 0.190 & 0.234 & 0.197 & 0.198 & 0.153 & 0.176 & 0.16 \\
\hline$\overline{\mathrm{OH}}+\mathrm{F}$ & 3.719 & 3.692 & 3.682 & 3.611 & 3.577 & 3.528 & 3.506 & 3.466 & 3.401 & 3.325 & 3.291 & 3.262 & 3.233 & 3.12 \\
\hline Bav \% & 14.3 & 15.5 & 16.0 & 19.2 & 21.2 & 23.7 & 24.7 & 26.7 & 30.0 & 33.5 & 35.1 & 36.8 & 38.5 & 42 \\
\hline
\end{tabular}




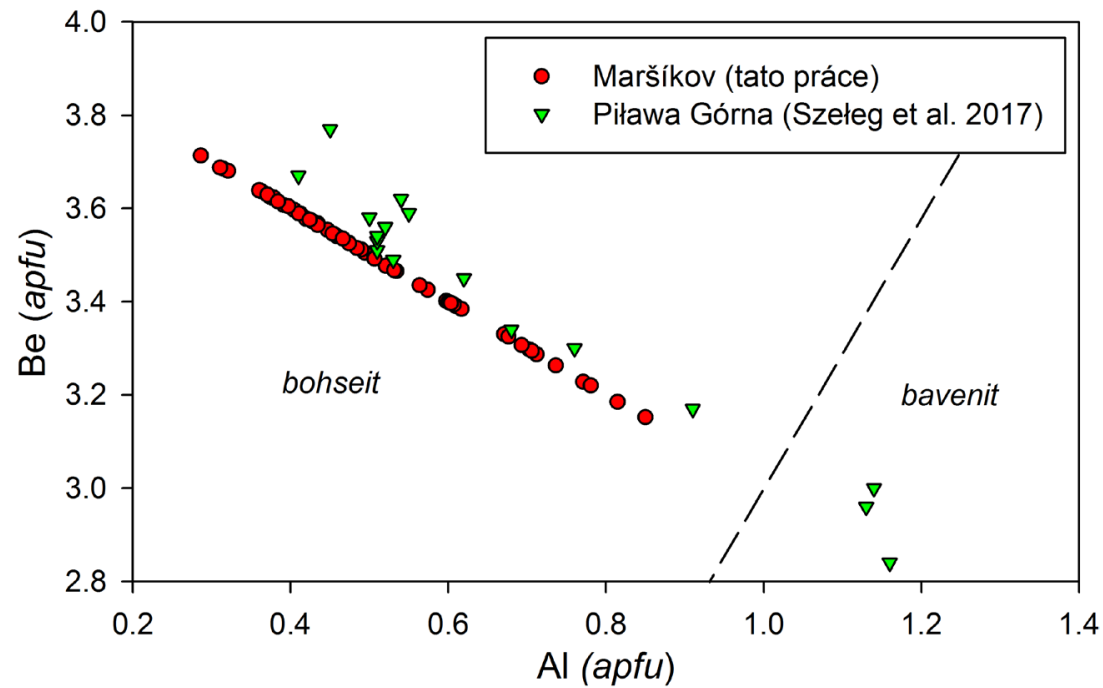

Obr. 5 Graf Al vs. Be (apfu) pro bohseit z Maršíkova a členy řady bohseit - bavenit z lokality Piława Górna (Szełeg et al. 2017).

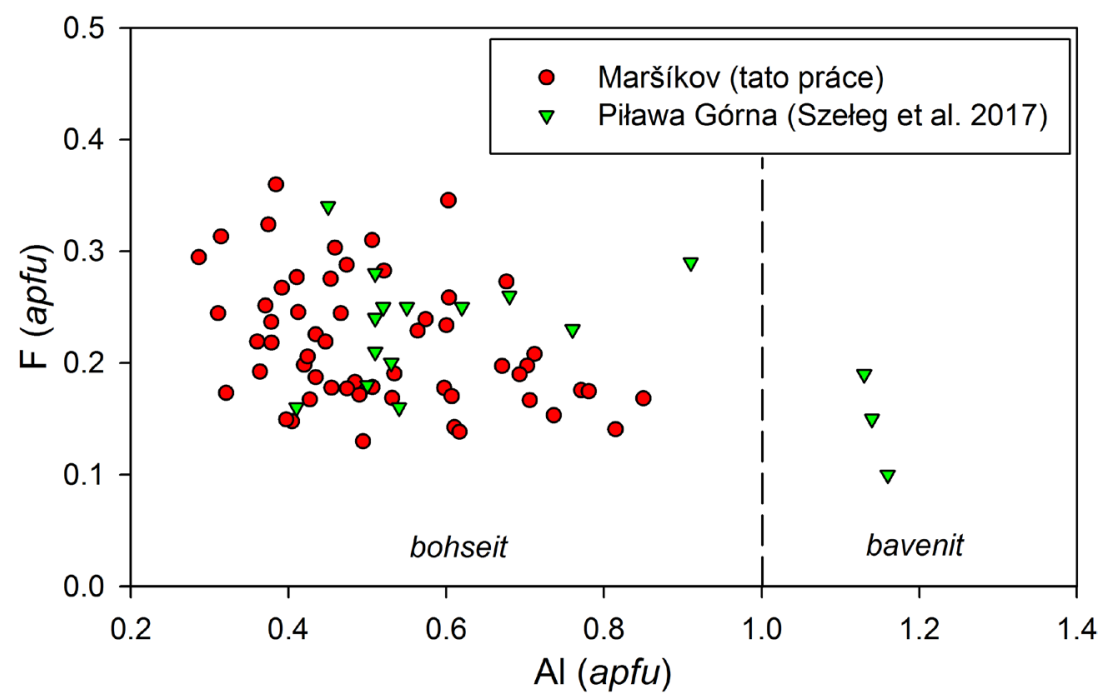

Obr. 6 Graf Al vs. F (apfu) pro bohseit z Maršíkova a členy rady bohseit - bavenit z lokality Piława Górna (Szełeg et al. 2017).

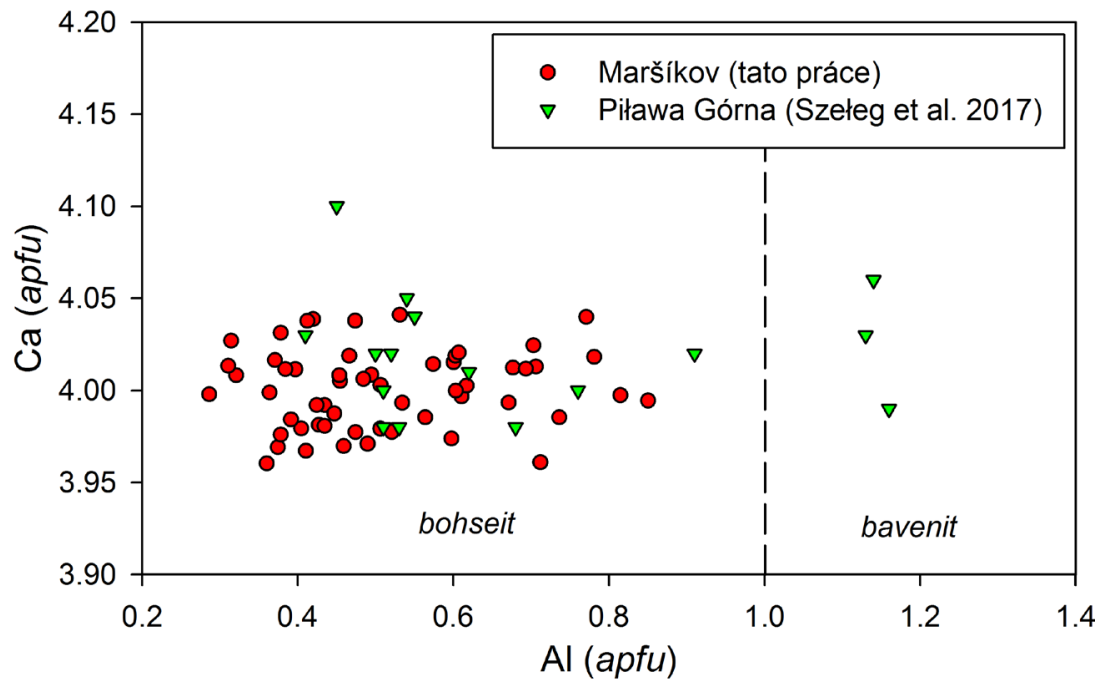

Obr. 7 Graf Al vs. Ca (apfu) pro bohseit z Maršíkova a členy rady bohseit - bavenit z lokality Piława Górna (Szełeg et al. 2017).

\section{Charakteristika bohseitu}

Bohseit byl identifikován ve vzorcích odebraných z hrubě zrnité texturně-paragenetické jednotky pegmatitu. Původně byl na základě vizuálního hodnocení považován za bavenit. Vytvárí až $10 \mathrm{~mm}$ velké, relativně málo soudržné agregáty křídově bílé barvy, složené z vějiŕovitě uspořádaných jehliček (obr. 3). Bohseit se charakteristicky vyskytuje v drobných (max. $2 \mathrm{~cm}$ velkých) dutinách pegmatitu (obr. 4) ve společnosti drobných krystalů křemene, albitu, aduláru, muskovitu a epidotu. Obvykle na výše zmíněné fáze narůstá, ojediněle byly zjištěny i intimní srůsty bohseitu s tenkými šupinami muskovitu.

Rentgenová prášková data bohseitu (tab. 1) jsou v dobré shodě $s$ publikovanými údaji pro tento minerální druh i teoretickým záznamem vypočteným z jeho krystalové struktury (Szełeg et al. 2017); významné rozdíly $v$ intenzitách jednotlivých difrakčních maxim jsou vyvolány přednostní orientací vyvolanou dokonalou štěpností podle $\{h 00\}$ a jehlicovitým charakterem vzorku. Zpřesněné parametry jeho základní cely jsou $v$ tabulce 2 porovnány $s$ publikovanými údaji; bohseit se od bavenitu odlišuje zejména nižšími hodnotami parametrů $b$ a $c$, velikost parametru a je srovnatelná.

Chemické složení bohseitu bylo studováno prostřednictvím 55 bodových WDS analýz. Výběr získaných analýz je uveden $v$ tabulce 3 . Chemické složení je poměrně jednoduché, vedle Si a Ca byly v dané fázi naměřeny jen slabě zvýšené obsahy Al, Na a F. Při přepočtu empirického vzorce na základ devíti atomů křemíku Ize konstatovat obsahy Ca v intervalu 3.96 - 4.04 apfu, Al v intervalu 0.29 - 0.85 apfu, $\mathrm{Na}$ mezi 0 a 0.06 apfu a $F$ mezi 0.13 a 0.36 apfu. Obsahy mikrosondou neměřitelných složek ( $\mathrm{OH}$ a Be), dopočtené ze stechiometrie bohseit -bavenitové substituce, se pohybují v intervalu 2.98 - 3.51 apfu $\left(\mathrm{OH}^{-}\right)$, respektive 3.15 - 3.69 apfu $(\mathrm{Be}$; tab. 3). Obsah bavenitové složky se v analyzované fázi tedy pohybuje mezi 14.3 a 42.5 mol. \%, takže jde klasifikačně ve všech prípadech o bohseit (obr. 5).

Ze srovnání chemického složení bohseitu z Maršíkova s nehojnými publikovanými údaji $\mathrm{k}$ chemismu této fáze vyplývá značná podobnost rozsahů chemického složení (obr. 6 
a 7). Část analýz z Maršíkova (tato práce) a z třebíčského masivu (Zachař, Škoda 2019) vykazuje dokonce poněkud vyšší obsah bohseitového koncového členu než má typová lokalita Pilawa Górna (Szełeg et al. 2017), kde některé analýzy již spadají do pole bavenitu (obr. 5). Tento posun v chemismu bohseitu z českých lokalit svědčí o výraznějším uplatnění beryllia oproti hliníku během alteračních hydrotermálních procesů, během nichž dané minerální fáze vznikaly. Výrazné variabilitě v aktivitách obou prvků na námi studované lokalitě nasvědčuje i př́tomnost dalších hydrotermálních fází s různým obsahem $\mathrm{Al}$ a $\mathrm{Be}$ bertranditu a milaritu.

\section{Závěr}

Prášková rentgenová difrakční analýza a stanovení chemického složení na elektronové mikrosondě identifikovaly křídově bílý minerál z beryl-columbitového pegmatitu D6e u Maršíkova, který byl na základě dřivějšího makroskopického určení považován za bavenit, jako bohseit. Vyskytuje se nejčastěji v drobných dutinkách pegmatitu $v$ asociaci s drobnými krystaly křemene, albitu, aduláru, muskovitu a epidotu. Př́tomnost a chemické složení bohseitu svědčí o výrazné frakcionaci Be a Al během postmagmatických hydrotermálních alterací pegmatitu. Zdrojem Be byl beryl, který je $v$ pegmatitu relativně hojně př́tomen a místy $v$ důsledku alteračních procesů i zcela vyloužen.

\section{Poděkování}

Práce na článku byly finančně podpořeny Ministerstvem kultury ČR $v$ rámci institucionálního financování výzkumné organizace Národní muzeum (DKRVO 20192023/1.II.b, 00023272).

\section{Literatura}

BuRNhAM CHW (1962) Lattice constant refinement. Carnegie Inst Washington Year Book 61: 132-135

DostÁl J (1964) Pegmatity z okolí Maršíkova. MS, diplomová práce, UK Praha

CHLÁdeK Š, Uher P (2020) Komplexní magmaticko-hydrotermální vývoj columbitu, mikrolitu a fersmitu: př́klad z beryl-columbitového pegmatitu D6e u Maršíkova, Česká republika. Bull Mineral Petrol 28(1): 23-34

Kruťa T, Paděra K, Pouba Z, Sládek R (1968) Die Mineralienparagenese in dem mittleren Teile des Altvatergebirges (Hrubý Jeseník, Hohes Gesenke, ČSSR), Fortsetzung. Acta Mus Moraviae 53: 5-80

LUSSIER AJ, HAWTHORNE FC (2011) Short-range constraints on chemical and structural variations in bavenite. Mineral Mag 75(1): 213-239

ONDRUŠ P (1993) ZDS - A computer program for analysis of X-ray powder diffraction patterns. Materials Science Forum, 133-136, 297-300, EPDIC-2. Enchede

Pouchou JL, PICHOIR F (1985) "PAP" ( $\varphi \rho Z)$ procedure for improved quantitative microanalysis. In: ARMSTRONG JT (ed.) Microbeam Analysis: 104-106. San Francisco Press, San Francisco.

Szetęg E, Zuzens B, Hawthorne FC, Pieczka A, Szuszkiewicz A, Turniak K, Nejbert K, ILNICKI SS, Frils H, Makovicky E, Weller MT, Lemée-Cailleau M-H (2017) Bohseite, ideally $\mathrm{Ca}_{4} \mathrm{Be}_{4} \mathrm{Si}_{9} \mathrm{O}_{24}(\mathrm{OH})_{4}$, from the Piława Górna quarry, the Góry Sowie Block, SW Poland. Mineral Mag 81: 35-46

ZACHAŘ A, ŠKoDA R (2019) Bohseite-bavenite from intragranitic NYF pegmatites of the Třebič Pluton. In Book of abstracts of the $9^{\text {th }}$ European Conference on the Mineralogy and Spectroscopy, September 11-13, Prague, nestr. 